\title{
Stem Cell Differentiation: Cardiac Repair
}

\author{
Michael Rubart Loren J. Field \\ Division of Pediatric Cardiology, Herman B Wells Center for Pediatric Research, and Krannert Institute of Cardiology, \\ Indiana University School of Medicine, Indianapolis, Ind., USA
}

\section{Key Words}

Cardiac regeneration $\cdot$ Cell transplantation $\cdot$ Clinical studies $\cdot$ Heart disease

\begin{abstract}
Cellular transplantation has been employed for several years to deliver donor cardiomyocytes to normal and injured hearts. Recent reports of a variety of stem cells with apparent cardiomyogenic potential have raised the possibility of cell transplantation-based therapeutic interventions for heart disease. Here we review the preclinical studies demonstrating that intracardiac transplantation of skeletal myoblasts, cardiomyocytes and cardiomyogenic stem cells is feasible. In addition, recent clinical studies of skeletal myoblast and adult stem cell transplantation for heart disease are discussed.

Copyright $\odot 2007$ S. Karger AG, Basel
\end{abstract}

\section{Introduction}

The concept of cell transplantation as a means to increase myocyte number in injured hearts first appeared in the early 1990s. The approach is based on the notion that transplantation of cardiomyocytes, or alternatively cardiomyogenic stem cells, will result in the formation of new cardiac muscle in the recipient heart. It is assumed that if a sufficient number of donor cells engraft, and if these cells are able to participate in a functional syncytium with the host myocardium, improvement in cardiac output would be achieved.

\section{KARGER}

Fax +4161306 1234

E-Mail karger@karger.ch

www.karger.com
(C) 2007 S. Karger AG, Basel

$1422-6405 / 08 / 1882-0202 \$ 24.50 / 0$

Accessible online at:

www.karger.com/cto
Initial cardiac cell transplantation efforts utilized skeletal myoblasts (SMBs), an adult-derived stem cell which can differentiate into skeletal myofibers in vitro and in vivo. The observation that SMB transplantation could improve cardiac function in the absence of bona fide cardiomyogenic differentiation ultimately led to the notion that donor cells could have 'secondary' beneficial effects in injured hearts. Indeed, it is now apparent from experiments using a variety of donor cell types that cell transplantation can antagonize adverse cardiac remodeling and promote cardioprotection following transplantation into injured hearts. Other studies examined the use of fetal or neonatal cardiomyocytes as donor cells. These latter studies clearly established that exogenous cells can structurally and functionally integrate into the host myocardium.

More recently, both embryonic and adult-derived stem cells have been examined for cardiomyogenic differentiation in vitro, and following transplantation into normal and injured hearts. In many instances, markedly differ-

\begin{tabular}{ll} 
Abbreviations used in this paper \\
\hline BMCs & bone marrow cells \\
CPCs & $\begin{array}{l}\text { circulating progenitor cells } \\
\text { ejection fraction }\end{array}$ \\
EF & enhanced green fluorescent protein \\
EGFP & embryonic stem cells \\
ESCs & granulocyte colony-stimulating factor \\
G-CSF & left ventricular \\
LV & skeletal myoblasts \\
SMBs &
\end{tabular}

Dr. Loren J. Field

Wells Center, 1044 West Walnut Street

R4 Building, Room W376

Indianapolis, IN 46202-5225 (USA)

Tel. +1 317274 5085, Fax +1 317274 8679, E-Mail ljfield@iupui.edu 
ent results have been obtained with regards to the degree of cardiomyogenic differentiation with adult stem cells. Despite the clear absence of cardiomyogenic differentiation and/or the absence of donor cell retention in some studies, improvement in cardiac function following cell transplantation was observed, which again was likely attributable to the secondary effects mentioned above.

Here we provide a brief review of the field of cardiomyocyte and cardiomyogenic stem cell transplantation for the treatment of heart disease.

\section{SMB Transplantation from Bench to Bedside}

The first successful intracardiac engraftment of SMBs was reported in 1993 and utilized an established myoblast cell line. In this study, C2C12 SMBs were transplanted into the heart of syngenic $\mathrm{C} 3 \mathrm{Heb} / \mathrm{FeJ}$ mice [Koh et al., 1993]. Light microscopy and ultrastructural analyses revealed that the donor cells formed differentiated skeletal myotubes, and were viable for as long as 3 months after implantation (the latest time point analyzed). The donorderived skeletal myotubes were observed to be roughly aligned with host cardiomyocytes. The presence of donor grafts was not associated with overtly deleterious effects on the host myocardium (as monitored by surface electrocardiograms and plasma enzyme levels).

Several studies were performed to determine if SMBs could impact upon cardiac function following transplantation into injured hearts. For example, neonatal SMBs were transplanted into the heart of syngeneic adult rats following a freeze-thaw cryoinjury [Murry et al., 1996]. Multinucleated myotubes were observed within 3 days of transplantation, and by 7 weeks the grafts began expressing $\beta$-myosin heavy chain (a marker of slow-twitch fibers). Wound strips harvested from 2-week-old grafts developed tetanus when stimulated at high frequency ex vivo, suggesting that the SMB-derived myotubes retained physiologic attributes of skeletal muscle. In another study, autologous SMBs were transplanted into rabbits following cryoinjury [Taylor et al., 1998]. Histologic analyses revealed the presence of striated muscle grafts within the infarct tissue in roughly $50 \%$ of the rabbits receiving cell transplants when analyzed at 3-6 weeks after transplantation. Functional analyses with ultrasonic dimension transducers indicated improvement in cardiac function in animals exhibiting cell grafts at necropsy compared to those lacking grafts.

The mechanism of functional improvement following SMB transplantation was subject to considerable debate, which was fueled in part by the suggestion that SMB-derived cells might differentiate into cardiomyocytes. Two experiments were performed to address this issue at the functional level. In the first study, primary rat SMBs were transfected in vitro with adenovirus expressing an enhanced green fluorescent protein (EGFP) reporter transgene [Leobon et al., 2003]. The cells were then transplanted into myocardial scar 1 week following permanent coronary artery occlusion. Fluorescent dye injected into EGFP-expressing myotubes in vibratome sections prepared from the hearts at 4 weeks after transplantation did not transfer to adjacent myotubes or into host myocardium. Moreover, intracellular recording and motion detection analyses revealed that neither spontaneous nor evoked contractions propagated between the donor-derived myotubes and the host myocardium.

In the second study, SMBs isolated from transgenic mice with a ubiquitously expressed EGFP reporter transgene were injected into uninjured mouse hearts [Rubart et al., 2004]. Hearts were harvested between 11 and 106 days after transplantation, subjected to retrograde perfusion with rhod-2 (a calcium indicator dye) and cytochalasin D (an excitation/contraction uncoupler), and then imaged via 2-photon laser scanning microscopy. The presence of the EGFP reporter permitted identification of donor versus host cells, while the rhod-2 indicator permitted assessment of calcium transient (and by inference, action potential) propagation. In agreement with the results of Leobon et al. [2003], the vast preponderance of donor-derived myocytes were functionally isolated from the host myocardium. However, a very small number of EGFP-expressing cells were observed to be electrically coupled with the host myocardium (fewer than 7 cells per heart), which appear to have arisen as a consequence of fusion events between donor SMBs and host cardiomyocytes. Tetanus was readily induced in these heterokaryons, indicating that they retained electrical properties typical of skeletal myocytes. The inability of donor-derived skeletal myocytes to participate in a functional syncytium with the host myocardium strongly implied that any positive effect on cardiac function following transplantation into injured hearts is due to secondary effects of the cells.

These results have sparked a series of phase 1 clinical trials that were designed to test the feasibility and safety of autologous SMB transfer in patients with severe postinfarction left ventricular (LV) dysfunction. In the first study, $\sim 900$ million autologous SMBs were injected into myocardial scars of 10 patients (LV ejection fraction, EF, $\leq 35 \%$ ) during coronary artery bypass surgery [Menasche 
et al., 2003]. A 7\% increase in EF as measured by transthoracic echocardiography, with a concomitant improvement in clinical status, was observed at an average followup of 11 months. Four of the patients experienced sustained ventricular tachycardia, requiring implantation of internal cardioverters/defibrillators. Autopsy of 1 patient, who died from a presumed stroke at 17.5 months after surgery, revealed clusters of myotubes within the myocardial scar, although myotube number was not quantified. Follow-up study of the surviving 9 patients at an average of 52 months after surgery confirmed stable improvement in both clinical state and global ventricular function, as well as effective control of ventricular tachyarrhythmias by the implanted antiarrhythmia devices [Hagege et al., 2006]. Given that the patients received bypass grafts, the degree to which cell transplantation impacted function could not be ascertained in these studies. Additionally, 2 of the patients were implanted with ventricular resynchronization pacemakers for treatment of refractory congestive heart failure. This intervention also was likely to have contributed, at least in part, to the positive long-term results in this patient cohort.

In a similar study, patients with ischemic cardiomyopathy $(\mathrm{EF}<40 \%)$ undergoing either coronary artery bypass grafting or implantation of a LV assist device received direct intramyocardial injections of autologous SMBs at escalating doses (10-300 million) [Dib et al., 2005]. An average increase in LV EF of $8 \%$ was apparent at 6 months, which persisted for 2 years, with a concomitant improvement in clinical status. Interestingly, histological analyses in 4 of 6 patients who underwent heart transplantation demonstrated the presence of multinucleated, MY-32-positive skeletal myotubes in scarred myocardial tissue at 5 days to 6 months after cell injection. Graft sizes were not quantitated. Two additional phase 1 clinical trials confirmed the procedural safety and similarly found stable improvement in functional and clinical outcome up to 1 year following surgery [Siminiak et al., 2004; Gavira et al., 2006].

Nonsurgical approaches for SMB delivery have also been tested. In one study, autologous SMB transplantation (17-106 million cells per patient) in 10 postinfarction patients (interval between myocardial infarction and transplantation: 5 months to 8 years) using a catheterbased transvascular approach for cell delivery resulted in clinical improvement [Siminiak et al., 2005]. Interesting$l y$, the extent of functional improvement did not correlate with the number of cells injected. Two additional trials have utilized endoventricular catheters to introduce cells during electromechanical mapping [Brasselet et al., 2005;
Biagini et al., 2006]. Both studies reported an improvement in regional and/or global LV function up to 1 year after cell transfer, although no data demonstrating stable SMB engrafted was presented.

Collectively, phase 1 clinical trials in patients with severe postinfarction LV dysfunction did not appear to be associated with a significant procedural risk, however, increased incidence of ventricular arrhythmias following SMB injection in several studies remained a major safety concern. All studies uniformly demonstrated the feasibility of growing large quantities of SMBs ex vivo from small muscle biopsies. None of the phase 1 clinical trials were designed to examine the efficacy of autologous SMB transfer for treatment of congestive heart failure in patients with ischemic cardiomyopathy. In fact, although short- and long-term follow-up suggested a moderate, yet significant, increase in LV EF, as measured by echocardiography, it has been impossible to unambiguously ascribe those improvements to the engraftment of cells.

\section{Proof of Concept Studies with Fetal Cardiomyocyte Transplantation}

The initial study demonstrating transplantation of cardiomyocytes into adult hearts utilized a cardiomyocyte-restricted nuclear localized $\beta$-galactosidase reporter transgene to monitor donor cell fate [Soonpaa et al., 1994]. Embryonic cardiomyocytes isolated from the transgenic reporter mice were transplanted into uninjured syngeneic adult hearts, and donor cells were subsequently identified by histochemical staining with a chromogenic $\beta$-galactosidase substrate. Light microscopic analyses revealed the presence of well-differentiated donor cardiomyocytes which were closely juxtaposed with host cardiomyocytes. Subsequent transmission electron microscopy analyses revealed the presence of mature intercalated discs comprised of fascia adherens and gap junctional complexes between donor (identified by the presence of the electron-dense $\beta$-galactosidase reaction product) and host cardiomyocytes [Koh et al., 1995].

Although the ultrastructural characteristics of the donor and host cardiomyocyte junctional complexes strongly suggested that they were functionally coupled, direct proof required the development of the 2-photon laser scanning microscopy-based imaging assay described above. Donor cells expressing a cardiomyocyte-restricted EGFP reporter transgene were isolated from embryonic hearts and transplanted directly into the hearts of nontransgenic adult recipients. The hearts were subsequently 
harvested, perfused with cytochalasin D and rhod-2, and imaged. Spontaneous and evoked action potential propagation, as inferred by the presence of transient increases in rhod-2 fluorescence, were observed to occur simultaneously in donor and host cardiomyocytes, indicative of physiologic coupling [Rubart et al., 2003]. Calcium transient characteristics were indistinguishable between the donor and host cardiomyocytes, and remarkably all donor cells which were in contact with host cardiomyocytes were observed to be functionally coupled. These data indicate that fetal cardiomyocytes can readily electrically integrate, and thus form a functional syncytium, with the host myocardium.

Given these results, it is not surprising that a number of studies have examined the consequences of fetal and neonatal cardiomyocyte transplantation in injured hearts. Although this area has recently been reviewed in detail [Dowell et al., 2003], several early studies warrant consideration here. For example, fetal cardiomyocytes transplanted into the hearts of rats 4 weeks following cryoinjury formed stable grafts comprised of well-differentiated cells. An improvement in cardiac function (inferred from developed pressure measurements on a Langendorff apparatus with an intraventricular balloon) was observed at 8 weeks after injury in the engrafted hearts compared to nonengrafted animals [Li et al., 1996]. However, the small size, anatomical location and architecture of the donor cardiomyocyte grafts strongly suggested that improvement in cardiac function was not a consequence of the contractile activity of the donor cells. Rather, the absence of infarct expansion and concomitant LV dilation in the cell-treated animals strongly suggests that the functional improvement resulted from attenuated adverse postinjury remodeling, similar to that observed with SMB transplantation described above. In agreement with this, an equivalent improvement in cardiac function was observed in rats with coronary artery ligation following transplantation of fetal cardiomyocytes or SMBs, compared to nonengrafted infarcted hearts [Scorsin et al., 2000].

\section{Embryonic Stem Cell-Derived Cardiomyocytes}

Embryonic stem cells (ESCs) are derived from the inner cell mass of blastocysts, and can be propagated in vitro in an undifferentiated state by coculturing with mitomycin-treated embryonic fibroblasts, which secrete cytokines that suppress differentiation. For mouse ESCs, the relevant cytokine is leukemia inhibitory factor. When grown in suspension culture in medium lacking differen- tiation-suppressing cytokines, ESCs will form spherical multicellular structures called embryoid bodies. Stochastic inductive cues occurring within the embryoid bodies promote differentiation, and cell types deriving from all 3 embryonic lineages typically appear, including spontaneously contracting cardiomyocytes. Similar results are observed with mouse [Doetschman et al., 1985] and human [Kehat et al., 2001, Mummery et al., 2002] ESCs, and numerous studies have shown that ESCs generate bona fide cardiomyocytes with attributes of the atrial, ventricular or conducting myocardium [for review, see Rubart et al., 2006]. Interestingly, an ESC-like cell with cardiomyogenic potential was recently obtained from cultured spermatogonial stem cells [Guan et al., 2006].

ESC-derived cardiomyocytes were examined for their ability to engraft into normal and injured myocardium. Because cardiomyocytes typically comprise only a small percentage of the cell types in spontaneously differentiating ESC cultures, a number of enrichment schemes have been employed to obtain sufficient cells for transplantation. For example, ESCs carrying a transgene encoding aminoglycoside phosphotransferase under the transcriptional regulation of a cardiomyocyte-restricted promoter were allowed to undergo spontaneous differentiation. Treatment of the cultures with the neomycin analogue G418 resulted in essentially pure (>99\%) populations of cardiomyocytes [Klug et al., 1996]. This selection protocol was readily converted to bioreactor cultures, and more than $10^{9}$ ESC-derived cardiomyocytes were produced from a 2-liter reactor vessel [Schroeder et al., 2005]. Murine ESC-derived cardiomyocytes were also enriched via fluorescence-activated cell sorting following transfection of a lineage-restricted fluorescence reporter [Muller et al., 2000], an approach which has recently been shown to work with human ESCs [Huber et al., 2007]. Considerable effort has also been invested in identifying combinatorial growth factor treatments which enhance cardiomyogenic differentiation (and consequently, yield) in ESC cultures [for review, see Rubart et al., 2006]. Interestingly, recent studies have shown that both vascular cells and cardiomyocytes arise from a common progenitor cell in differentiating ESC cultures [Kattman et al., 2006; Moretti et al., 2006; Wu et al., 2006], raising the possibility that transplantation of such cells might result in restoration of contractile cell mass as well as enhanced perfusion of the graft.

A number of studies have examined ESC-derived cardiomyocytes following intracardiac engraftment. When transplanted into the heart of normal syngeneic hosts, genetically selected ESC-derived cardiomyocytes sur- 
vived and formed well-differentiated grafts [Klug et al., 1996]. Human ESC-derived cardiomyocytes can also engraft following transplantation into normal ventricle. For example, populations of spontaneously contracting human ESC-derived cardiomyocytes (enriched by microdissection) were transplanted into the hearts of pigs with surgically induced complete atrial-ventricular conduction block. Histochemical analyses revealed that the transplanted cells survived, and the presence of pacing activity originating from the site of engraftment was interpreted as being indicative of functional coupling between the donor and host cardiomyocytes [Kehat et al., 2004]. Similarly, physically enriched human ESC-derived cardiomyocytes transplanted into guinea pig hearts were able to drive pacemaker activity in vitro after ablation of the atrioventricular node [Xue et al., 2005]. Surprisingly, human ESC-derived cardiomyocytes retained a relatively high level of cell cycle activity following transplantation [Laflamme et al., 2005], which, if sustained, would result in larger grafts over time.

ESCs and ESC-derived cardiomyocytes have also been transplanted into injured hearts [for review, see Rubart et al., 2006]. As was observed with fetal cardiomyocyte grafts, transplantation of enriched populations of mouse ESC-derived cardiomyocytes into hearts with experimental infarcts in many instances led to an improvement in cardiac function. However, quantitative assessment of donor cardiomyocyte survival typically was not performed and, consequently, it cannot be determined if the improved cardiac function resulted from the contractile activity of the ESC-derived cardiomyocytes or, alternatively, from some other activity of these cells. Given the small graft size observed in many of these studies, it is almost certain that the benefit resulted at least in part from indirect effects of the donor cells.

\section{Adult-Derived Stem Cells with Apparent Cardiomyogenic Potential}

The notion that cardiomyogenic cells may be present in adult mammals has received considerable interest lately. Early evidence suggesting the presence of such cells came from bone marrow transplantation studies wherein genetically marked marrow stem cells were delivered into animals lacking the marker; the presence of a small number of cardiomyocytes carrying the genetic marker was interpreted to represent cardiomyogenic events [Bittner et al., 1999; Jackson et al., 2001]. Subsequent studies demonstrated that such cells can arise from fusion events be- tween resident cardiomyocytes and the transplanted stem cells [Alvarez-Dolado et al., 2003]. A similar phenomenon appears to occur in human hearts following sex-mismatch transplantation, although the reported prevalence of such events ranged over 4 orders of magnitude [Hruban et al., 1993; Glaser et al., 2002; Laflamme et al., 2002; Quaini et al., 2002].

Other studies suggested that marrow-derived hematopoietic cells with cardiomyogenic potential could be mobilized with granulocyte colony-stimulating factor (GCSF) [Orlic et al., 2001a] or directly injected in injured myocardium [Orlic et al., 2001b], resulting in the formation of new cardiac muscle mass and a concomitant improvement in cardiac function. In contrast, several groups failed to observe significant cardiomyogenic activity following cytokine-mediated mobilization of hematopoietic stem cells [Kawamoto et al., 2004; Nygren et al., 2004; Deindl et al., 2006], although the procedure did appear to enhance postinjury cardiac function secondarily to enhanced cardiac perfusion (particularly when used in conjunction with vascular endothelial growth factor gene transfer). Similarly, studies from a number of other groups failed to detect cardiomyogenic activity following direct intracardiac injection of hematopoietic stem cells [Balsam et al., 2004; Murry et al., 2004; Nygren et al., 2004], suggesting any functional improvement once again was due to indirect effects. This point was elegantly demonstrated in a series of experiments utilizing Akt-expressing mesenchymal stem cells. In the initial study, transplantation of the stem cells resulted in a marked reduction in infarct size and a concomitant improvement in cardiac function compared to untreated hearts [Mangi et al., 2003]. Although there appeared to be a small number of cardiomyocytes derived from the transplanted stem cells, these would be too few to impact upon function [Noiseux et al., 2006], again suggesting that alternative mechanisms contributed to functional improvement. In support of this, injection of conditioned medium from cultured stem cells completely recapitulated the effect observed with stem cell transplantation [Gnecchi et al., 2006], indicating that a paracrine activity underlies the cardioprotection observed with this model. This view was recently confirmed by the isolation of the molecule responsible, Sfrp2 [Mirotsou et al., 2007].

Several reports have suggested that the adult heart also contains cells with cardiomyogenic potential. For example, one study suggested that progenitor cells expressing the c-kit receptor could be propagated in an undifferentiated state in vitro, and would contribute to neocardiomyogenesis upon transplantation into injured myocar- 
dium [Beltrami et al., 2003]. However, subsequent studies attempting to confirm these results revealed that the cardiac c-kit-expressing cells were in fact derived from the marrow, and exhibited cardioprotective rather than cardiomyogenic activity [Fazel et al., 2006]. The observed cardioprotection was attributed to a stem cell-induced proangiogenic milieu, resulting from increased vascular endothelial growth factor levels and a more favorable ratio of angiopoietin-1 to angiopoietin-2. Progenitor cells from the adult heart expressing the Sca-1 receptor were reported to home to injured myocardium and exhibit both fusiogenic and cardiomyogenic activity following intravenous delivery [Oh et al., 2003]. Other studies suggested that direct transplantation of these cells into injured hearts enhanced angiogenesis with a concomitant improvement in cardiac function, in the absence of cardiomyogenic activity [Wang et al., 2006]. Several other adult cardiac resident cells with apparent cardiomyogenic activity have been reported [Hierlihy et al., 2002; Messina et al., 2004], although follow-up analyses on these cell types have been limited.

\section{Clinical Studies with Circulation- and Marrow-Derived Progenitors}

A number of phase 1 clinical trials have established that intracardiac transplantation of peripheral- and marrow-derived stem cells is both safe and feasible, prompting a series of phase $2 / 3$ random trials to directly investigate the efficacy of autologous bone marrow cell (BMC) transfer to improve LV systolic function in patients with acute or chronic myocardial infarction. In the Bone Marrow Transfer to Enhance ST-Elevation Infarct Regeneration (BOOST) trial, 60 patients were randomized to receive either a single infusion of $\sim 3$ billion unfractionated BMCs into the infarct-related artery or no infusion within 5 days after successful reperfusion therapy [Wollert et al., 2004]. LV EF, measured by magnetic resonance imaging, was $6 \%$ greater in the BMC group than in the control group at 6-month follow-up. At 18-month follow-up, however, LV EF in the control group had approached the value in the BMC group, suggesting that the main effect was an acceleration of LV EF recovery after acute myocardial infarction by BMC transfer [Meyer et al., 2006].

Several other randomized, double-blind, placebocontrolled, multicenter studies have been conducted to evaluate the effectiveness of autologous BMC transfer in attenuating LV systolic dysfunction following acute myocardial infarction. One, the Reinfusion of Enriched Pro- genitor Cells and Infarct Remodeling in Acute Myocardial Infarction (REPAIR-AMI) trial, indicated that BMC transplantation has a positive effect. In this trial, 200 patients received either autologous BMCs (unfractionated mononucleated BMCs) or placebo (medium plus autologous serum) via infusion into the infarct-related artery within 3-7 days after successful reperfusion therapy [Schachinger et al., 2006]. At 4 months follow-up, the absolute increase in LV EF, measured by ventricular angiography, was significantly greater in the BMC group than in the placebo group (5.5 vs. 3.0\%). A subset analysis revealed that the benefit was greater in patients with the lowest EF at baseline. Although the study was not powered to evaluate the clinical outcome, it is interesting that the rate of combined clinical endpoints (death, recurrence of myocardial infarction, revascularization procedure) was significantly lower at 1 year among patients receiving $\mathrm{BMC}$ than among those receiving placebo. Data on ventricular function at 1 year are not yet available.

In contrast, the Autologous Stem-Cell Transplantation in Acute Myocardial Infarction (ASTAMI) trial found no statistical evidence for a beneficial effect of autologous BMC transfer on LV EF, measured by 3 independent noninvasive imaging methods, at 6 months in the $\mathrm{BMC}$ group, compared with the control group (no bone marrow aspiration, no sham injection; Lunde et al., 2006). Similarly, Janssens et al. [2006] were unable to find a significant effect of intracoronary BMC injection on global $\mathrm{EF}$ in patients after successful percutaneous reperfusion therapy for acute myocardial infarction, although infarct size was significantly reduced and systolic function of the reperfused myocardium showed better recovery.

So far, only 1 randomized study has examined the effectiveness of bone marrow or progenitor cell transfer in improving LV EF in patients with chronic myocardial infarction and moderately reduced LV function (EF at baseline $\sim 40 \%$ ). In the Transplantation of Progenitor Cells and Recovery of LV Function in Patients with Chronic Ischemic Heart Disease (TOPCARE-CHD) trial, a randomized crossover trial, the absolute change in LV EF at 3 months, measured by ventricular angiography, was significantly greater among patients receiving BMC than among those receiving circulating progenitor cells (CPCs) [Assmus et al., 2006]. After initial treatment with one cell type, the groups received the other cell type in the next phase of the trial, but the result was independent of the order in which the cells were administered, suggesting a BMC-specific effect. This study implies that BMC can have effects other than acceleration of LV EF recovery after acute myocardial infarction. 
Although the case for cardiomyogenic induction following cytokine-mediated stem cell mobilization is not strong, clinical trials have been performed in the hope of impacting cardiac function via altered perfusion (see above). For example, several uncontrolled phase 1 trials have suggested that delivery of G-CSF after treatment of ST-elevation myocardial infarction via percutaneous reperfusion therapy resulted in enhanced LV function and systolic wall thickening compared to reperfusion therapy alone [Ince et al., 2005a, b; Valgimigli et al., 2005]. However, 3 double-blind, randomized, placebo-controlled trials failed to confirm these results [Engelmann et al., 2006; Ripa et al., 2006; Zohlnhofer et al., 2006]. Although percutaneous reperfusion therapy alone resulted in improved cardiac function in these studies, combined treatment with G-CSF had no additional benefit. Moreover, G-CSF treatment failed to enhance cardiac function in patients with chronic ischemic heart disease [Hill et al., 2005; Wang et al., 2005]. Although these results are disappointing, it remains possible that treatment with multiple cytokines (perhaps in combination with stem cell therapy) will yield a more favorable outcome.

\section{Summary}

This review has provided an update of basic and clinical studies involving cell transplantation as a means to treat heart disease. The basic studies revealed that donor cardiomyocytes can successfully be transplanted into the myocardium and are able to participate in a functional syncytium with the host myocardium. Although donor SMBs differentiate into nascent myotubes and have a positive impact on adverse remodeling after transplantation, these cells remain electrically isolated from the host myocardium. The results with adult-derived stem cells are less clear. On one hand, the cardiomyogenic potential of many adult-derived stem cells has been called into question. On the other hand, transplantation of these cells can have a beneficial impact on cardiac function. In many cases this can occur in spite of the absence of cardiomyogenic differentiation, and for that matter, the absence of long-term retention of the donor cells. The clinical studies revealed that SMB, BMC and CPC transplantation appears to be well tolerated. Some studies indicated that transplantation of these cells can have a positive impact on cardiac remodeling, cardiac function and/or clinical outcome.

In light of this, future directions for both basic and clinical experimentation are clear. Minimally, 2 avenues of basic research are warranted. First, it is imperative to ascertain the molecular mechanism underlying the improvement in cardiac function seen with noncardiomyogenic cells. Studies from the Dzau laboratory characterizing the basis of mesenchymal stem cell-mediated cardioprotection [Mangi et al., 2003; Gnecchi et al., 2005, 2006; Noiseux et al., 2006; Mirotsou et al., 2007] are exemplary. Acquiring such mechanistic insight is imperative if one wishes to enhance the effectiveness of the intervention. Second, it is important not to give up on the ideal of true regeneration of lost myocardial mass (as opposed to the types of cardioprotective activities described above). Current cell transplantation approaches can clearly generate de novo functional myocardium in experimental animals, albeit in limited volumes. Enhancing donor cell seeding, survival and posttransplantational growth could result in replacement of transmural defects with nascent myocardium.

The current lack of a precise understanding of the mechanism underlying cell therapy-mediated improvement in LV function should not distract from future clinical trials. Future research in the field will most likely have to focus on the cell type(s) that best mediate(s) the benefits, on the requirement for stable engraftment for long-term therapeutic efficacy, and on the involvement of cytokines in this process. Indeed, based on the recent basic observations, activation of signaling cascades by secreted cytokines, ultimately giving rise to enhanced survival and/or contractility of host cardiomyocytes, constitutes a more realistic interpretation of the mechanisms underlying the apparent functional and clinical benefits of cardiac cell therapy in humans.

One should also keep in mind that increases in LV EF by only a few percent could potentially translate into significant improvements in clinical outcome. Thus, if SMB, $\mathrm{BMC}$ or CPC transfer exerts a beneficial effect in addition to that conferred by state-of-the-art therapy for systolic heart failure, then this would indeed constitute an important step toward improved treatment for patients with severe LV dysfunction. Additional long-term follow-up clinical studies are needed to clarify whether any cell transfer approach confers a sustained benefit over placebo treatment with regard to improvement in LV systolic function. Studies are also needed to determine whether increases in LV EF on the scale of a few percentages actually translate into improved clinical outcome, including morbidity and mortality. It is quite possible that the clinical benefits may exceed the seemingly modest improvement seen in LV performance. 


\section{References}

Alvarez-Dolado, M., R. Pardal, J.M. Garcia-Verdugo, J.R. Fike, H.O. Lee, K. Pfeffer, C. Lois, S.J. Morrison, A. Alvarez-Buylla (2003) Fusion of bone-marrow-derived cells with Purkinje neurons, cardiomyocytes and hepatocytes. Nature 425: 968-973.

-Assmus, B., J. Honold, V. Schachinger, M.B. Britten, U. Fischer-Rasokat, R. Lehmann, C. Teupe, K. Pistorius, H. Martin, N.D. Abolmaali, T. Tonn, S. Dimmeler, A.M. Zeiher (2006) Transcoronary transplantation of progenitor cells after myocardial infarction. N Engl J Med 355: 1222-1232.

Balsam, L.B., A.J. Wagers, J.L. Christensen, T. Kofidis, I.L. Weissman, R.C. Robbins (2004) Haematopoietic stem cells adopt mature haematopoietic fates in ischaemic myocardium. Nature 428: 668-673.

Beltrami, A.P., L. Barlucchi, D. Torella, M. Baker, F. Limana, S. Chimenti, H. Kasahara, M. Rota, E. Musso, K. Urbanek, A. Leri, J. Kajstura, B. Nadal-Ginard, Anversa, P. (2003) Adult cardiac stem cells are multipotent and support myocardial regeneration. Cell 114: 763-776.

Biagini, E., M. Valgimigli, P.C. Smits, D. Poldermans, A.F. Schinkel, V. Rizzello, E.E. Onderwater, M. Bountioukos, P.W. Serruys (2006) Stress and tissue Doppler echocardiographic evidence of effectiveness of myoblast transplantation in patients with ischaemic heart failure. Eur J Heart Fail 8: 641-648.

Bittner, R.E., C. Schofer, K. Weipoltshammer, S. Ivanova, B. Streubel, E. Hauser, M. Freilinger, H. Hoger, A. Elbe-Burger, F. Wachtler (1999) Recruitment of bone-marrow-derived cells by skeletal and cardiac muscle in adult dystrophic mdx mice. Anat Embryol (Berl) 199: 391-396.

Brasselet, C., M.C. Morichetti, E. Messas, C. Carrion, A. Bissery, P. Bruneval, J.T. Vilquin, A. Lafont, A.A. Hagege, P. Menasche, M. Desnos (2005) Skeletal myoblast transplantation through a catheter-based coronary sinus approach: an effective means of improving function of infarcted myocardium. Eur Heart J 26: 1551-1556.

Deindl, E., M.M. Zaruba, S. Brunner, B. Huber, U. Mehl, G. Assmann, I.E. Hoefer, J. MuellerHoecker, W.M. Franz (2006) G-CSF administration after myocardial infarction in mice attenuates late ischemic cardiomyopathy by enhanced arteriogenesis. FASEB J 20: 956958.

Dib, N., R.E. Michler, F.D. Pagani, S. Wright, D. J. Kereiakes, R. Lengerich, P. Binkley, D. Buchele, I. Anand, C. Swingen, M.F. Di Carli, J.D. Thomas, W.A. Jaber, S.R. Opie, A. Campbell, P. McCarthy, M. Yeager, V. Dilsizian, B.P. Griffith, R. Korn, S.K. Kreuger, M. Ghazoul, W.R. MacLellan, G. Fonarow, H.J. Eisen, J. Dinsmore, E. Diethrich (2005) Safety and feasibility of autologous myoblast transplantation in patients with ischemic cardiomyopathy: four-year follow-up. Circulation 112: 1748-1755.

Doetschman, T.C., H. Eistetter, M. Katz, W. Schmidt, R. Kemler (1985) The in vitro development of blastocyst-derived embryonic stem cell lines: formation of visceral yolk sac, blood islands and myocardium. J Embryol Exp Morphol 87: 27-45.

Dowell, J.D., M. Rubart, K.B. Pasumarthi, M.H. Soonpaa, L.J. Field (2003) Myocyte and myogenic stem cell transplantation in the heart. Cardiovasc Res 58: 336-350.

Engelmann, M.G., H.D. Theiss, C. HennigTheiss, A. Huber, B.J. Wintersperger, A.E. Werle-Ruedinger, S.O. Schoenberg, G. Steinbeck, W.M. Franz (2006) Autologous bone marrow stem cell mobilization induced by granulocyte colony-stimulating factor after subacute ST-segment elevation myocardial infarction undergoing late revascularization: final results from the G-CSF-STEMI (Granulocyte Colony-Stimulating Factor ST-Segment Elevation Myocardial Infarction) trial. J Am Coll Cardiol 48: 1712-1721.

Fazel, S., M. Cimini, L. Chen, S. Li, D. Angoulvant, P. Fedak, S. Verma, R.D. Weisel, A. Keating, R.K. Li (2006) Cardioprotective c-kit+ cells are from the bone marrow and regulate the myocardial balance of angiogenic cytokines. J Clin Invest 116: 18651877.

Gavira, J.J., M. Perez-Ilzarbe, G. Abizanda, A. Garcia-Rodriguez, J. Orbe, J.A. Paramo, M. Belzunce, G. Rabago, J. Barba, J. Herreros, A. Panizo, J.A. de Jalon, D. Martinez-Caro, F. Prosper (2006) A comparison between percutaneous and surgical transplantation of autologous skeletal myoblasts in a swine model of chronic myocardial infarction. Cardiovasc Res 71: 744-753.

Glaser, R., M.M. Lu, N. Narula, J.A. Epstein (2002) Smooth muscle cells, but not myocytes, of host origin in transplanted human hearts. Circulation 106: 17-19.

Gnecchi, M., H. He, O.D. Liang, L.G. Melo, F. Morello, H. Mu, N. Noiseux, L. Zhang, R.E. Pratt, J.S. Ingwall, V.J. Dzau (2005) Paracrine action accounts for marked protection of ischemic heart by Akt-modified mesenchymal stem cells. Nat Med 11: 367-368.

Gnecchi, M., H. He, N. Noiseux, O.D. Liang, L. Zhang, F. Morello, H. Mu, L.G. Melo, R.E. Pratt, J.S. Ingwall, V.J. Dzau (2006) Evidence supporting paracrine hypothesis for Aktmodified mesenchymal stem cell-mediated cardiac protection and functional improvement. Faseb J 20: 661-669.

Guan, K., K. Nayernia, L.S. Maier, S. Wagner, R. Dressel, J.H. Lee, J. Nolte, F. Wolf, M. Li, W. Engel, G. Hasenfuss (2006) Pluripotency of spermatogonial stem cells from adult mouse testis. Nature 440: 1199-1203.

Hagege, A.A., J.P. Marolleau, J.T. Vilquin, A. Alheritiere, S. Peyrard, D. Duboc, E. Abergel,
E. Messas, E. Mousseaux, K. Schwartz, M. Desnos, P. Menasche (2006) Skeletal myoblast transplantation in ischemic heart failure: long-term follow-up of the first phase I cohort of patients. Circulation 114: I108I113.

Hierlihy, A.M., P. Seale, C.G. Lobe, M.A. Rudnicki, L.A. Megeney (2002) The post-natal heart contains a myocardial stem cell population. FEBS Lett 530: 239-243.

Hill, J.M., M.A. Syed, A.E. Arai, T.M. Powell, J. D. Paul, G. Zalos, E.J. Read, H.M. Khuu, S.F. Leitman, M. Horne, G. Csako, C.E. Dunbar, M.A. Waclawiw, R.O. Cannon, 3rd (2005) Outcomes and risks of granulocyte colonystimulating factor in patients with coronary artery disease. J Am Coll Cardiol 46: 16431648.

-Hruban, R.H., P.P. Long, E.J. Perlman, G.M Hutchins, W.A. Baumgartner, K.L. Baughman, C.A. Griffin (1993) Fluorescence in situ hybridization for the Y-chromosome can be used to detect cells of recipient origin in allografted hearts following cardiac transplantation. Am J Pathol 142: 975-980.

-Huber, I., I. Itzhaki, O. Caspi, G. Arbel, M. Tzukerman, A. Gepstein, M. Habib, L. Yankelson, I. Kehat, L. Gepstein (2007) Identification and selection of cardiomyocytes during human embryonic stem cell differentiation. FASEB J 21: 2551-2563.

Ince, H., M. Petzsch, H.D. Kleine, H. Eckard, T. Rehders, D. Burska, S. Kische, M. Freund, C.A. Nienaber (2005a) Prevention of left ventricular remodeling with granulocyte colony-stimulating factor after acute myocardial infarction: final 1-year results of the Front-Integrated Revascularization and Stem Cell Liberation in Evolving Acute Myocardial Infarction by Granulocyte ColonyStimulating Factor (FIRSTLINE-AMI) Trial. Circulation 112: I73-I80.

Ince, H., M. Petzsch, H.D. Kleine, H. Schmidt, T. Rehders, T. Korber, C. Schumichen, M. Freund, C.A. Nienaber (2005b) Preservation from left ventricular remodeling by frontintegrated revascularization and stem cell liberation in evolving acute myocardial infarction by use of granulocyte-colony-stimulating factor (FIRSTLINE-AMI). Circulation 112: 3097-3106.

-Jackson, K.A., S.M. Majka, H. Wang, J. Pocius, C.J. Hartley, M.W. Majesky, M.L. Entman, L.H. Michael, K.K. Hirschi, M.A. Goodell (2001) Regeneration of ischemic cardiac muscle and vascular endothelium by adult stem cells. J Clin Invest 107: 1395-1402.

Janssens, S., C. Dubois, J. Bogaert, K. Theunissen, C. Deroose, W. Desmet, M. Kalantzi, L. Herbots, P. Sinnaeve, J. Dens, J. Maertens, F. Rademakers, S. Dymarkowski, O. Gheysens, J. Van Cleemput, G. Bormans, J. Nuyts, A. Belmans, L. Mortelmans, M. Boogaerts, F. Van de Werf (2006) Autologous bone mar- 
row-derived stem-cell transfer in patients with ST-segment elevation myocardial infarction: double-blind, randomised controlled trial. Lancet 367: 113-121.

Kattman, S.J., T.L. Huber, G.M. Keller (2006) Multipotent flk-1+ cardiovascular progenitor cells give rise to the cardiomyocyte, endothelial, and vascular smooth muscle lineages. Dev Cell 11: 723-732.

Kawamoto, A., T. Murayama, K. Kusano, M. Ii, T. Tkebuchava, S. Shintani, A. Iwakura, I. Johnson, P. von Samson, A. Hanley, M. Gavin, C. Curry, M. Silver, H. Ma, M. Kearney, D.W. Losordo (2004) Synergistic effect of bone marrow mobilization and vascular endothelial growth factor-2 gene therapy in myocardial ischemia. Circulation 110: 13981405.

Kehat, I., D. Kenyagin-Karsenti, M. Snir, H. Segev, M. Amit, A. Gepstein, E. Livne, O. Binah, J. Itskovitz-Eldor, L. Gepstein (2001) Human embryonic stem cells can differentiate into myocytes with structural and functional properties of cardiomyocytes. J Clin Invest 108: 407-414.

Kehat, I., L. Khimovich, O. Caspi, A. Gepstein, R. Shofti, G. Arbel, I. Huber, J. Satin, J. Itskovitz-Eldor, L. Gepstein (2004) Electromechanical integration of cardiomyocytes derived from human embryonic stem cells. Nat Biotechnol 22: 1282-1289.

Klug, M.G., M.H. Soonpaa, G.Y. Koh, L.J. Field (1996) Genetically selected cardiomyocytes from differentiating embronic stem cells form stable intracardiac grafts. J Clin Invest 98: 216-224.

Koh, G.Y., M.G. Klug, M.H. Soonpaa, L.J. Field (1993) Differentiation and long-term survival of $\mathrm{C} 2 \mathrm{C} 12$ myoblast grafts in heart. J Clin Invest 92: 1548-1554.

Koh, G.Y., M.H. Soonpaa, M.G. Klug, H.P. Pride, B.J. Cooper, D.P. Zipes, L.J. Field (1995) Stable fetal cardiomyocyte grafts in the hearts of dystrophic mice and dogs. J Clin Invest 96: 2034-2042.

Laflamme, M.A., D. Myerson, J.E. Saffitz, C.E. Murry (2002) Evidence for cardiomyocyte repopulation by extracardiac progenitors in transplanted human hearts. Circ Res 90: 634-640.

Laflamme, M.A., J. Gold, C. Xu, M. Hassanipour, E. Rosler, S. Police, V. Muskheli, C.E. Murry (2005) Formation of human myocardium in the rat heart from human embryonic stem cells. Am J Pathol 167: 663-671.

Leobon, B., I. Garcin, P. Menasche, J.T. Vilquin, E. Audinat, S. Charpak (2003) Myoblasts transplanted into rat infarcted myocardium are functionally isolated from their host. Proc Natl Acad Sci USA 100: 7808-7811.

Li, R.K., Z.Q. Jia, R.D. Weisel, D.A. Mickle, J. Zhang, M.K. Mohabeer, V. Rao, J. Ivanov (1996) Cardiomyocyte transplantation improves heart function. Ann Thorac Surg 62: 654-660; discussion 660-661.
Lunde, K., S. Solheim, S. Aakhus, H. Arnesen, M. Abdelnoor, T. Egeland, K. Endresen, A. Ilebekk, A. Mangschau, J.G. Fjeld, H.J. Smith, E. Taraldsrud, H.K. Grogaard, R. Bjornerheim, M. Brekke, C. Muller, E. Hopp, A. Ragnarsson, J.E. Brinchmann, K. Forfang (2006) Intracoronary injection of mononuclear bone marrow cells in acute myocardial infarction. N Engl J Med 355: 1199-1209.

Mangi, A.A., N. Noiseux, D. Kong, H. He, M. Rezvani, J.S. Ingwall, V.J. Dzau (2003) Mesenchymal stem cells modified with Akt prevent remodeling and restore performance of infarcted hearts. Nat Med 9: 1195-1201.

Menasche, P., A.A. Hagege, J.T. Vilquin, M. Desnos, E. Abergel, B. Pouzet, A. Bel, S. Sarateanu, M. Scorsin, K. Schwartz, P. Bruneval, M. Benbunan, J.P. Marolleau, D. Duboc (2003) Autologous skeletal myoblast transplantation for severe postinfarction left ventricular dysfunction. J Am Coll Cardiol 41: 10781083 .

Messina, E., L. De Angelis, G. Frati, S. Morrone, S. Chimenti, F. Fiordaliso, M. Salio, M. Battaglia, M.V. Latronico, M. Coletta, E. Vivarelli, L. Frati, G. Cossu, A. Giacomello (2004) Isolation and expansion of adult cardiac stem cells from human and murine heart. Circ Res 95: 911-921.

Meyer, G.P., K.C. Wollert, J. Lotz, J. Steffens, P. Lippolt, S. Fichtner, H. Hecker, A. Schaefer, L. Arseniev, B. Hertenstein, A. Ganser, H. Drexler (2006) Intracoronary bone marrow cell transfer after myocardial infarction: eighteen months' follow-up data from the randomized, controlled BOOST (BOne marrOw transfer to enhance ST-elevation infarct regeneration) trial. Circulation 113: 12871294.

Mirotsou, M., Z. Zhang, A. Deb, L. Zhang, M. Gnecchi, N. Noiseux, H. Mu, A. Pachori, V. Dzau (2007) Secreted frizzled related protein 2 (Sfrp2) is the key Akt-mesenchymal stem cell-released paracrine factor mediating myocardial survival and repair. Proc Natl Acad Sci USA 104: 1643-1648.

Moretti, A., L. Caron, A. Nakano, J.T. Lam, A. Bernshausen, Y. Chen, Y. Qyang, L. Bu, M. Sasaki, S. Martin-Puig, Y. Sun, S.M. Evans, K.L. Laugwitz, K.R. Chien (2006) Multipotent embryonic isl1+ progenitor cells lead to cardiac, smooth muscle, and endothelial cell diversification. Cell 127: 1151-1165.

Muller, M., B.K. Fleischmann, S. Selbert, G.J. Ji, E. Endl, G. Middeler, O.J. Muller, P. Schlenke, S. Frese, A.M. Wobus, J. Hescheler, H.A. Katus, W.M. Franz (2000) Selection of ventricular-like cardiomyocytes from ES cells in vitro. FASEB J 14: 2540-2548.

Mummery, C., D. Ward, C.E. van den Brink, S.D. Bird, P.A. Doevendans, T. Opthof, A. Brutel de la Riviere, L. Tertoolen, M. van der Heyden, M. Pera (2002) Cardiomyocyte differentiation of mouse and human embryonic stem cells. J Anat 200: 233-242.
Murry, C.E., R.W. Wiseman, S.M. Schwartz, S.D. Hauschka (1996) Skeletal myoblast transplantation for repair of myocardial necrosis. J Clin Invest 98: 2512-2523.

Murry, C.E., M.H. Soonpaa, H. Reinecke, H. Nakajima, H.O. Nakajima, M. Rubart, K.B. Pasumarthi, J.I. Virag, S.H. Bartelmez, V. Poppa, G. Bradford, J.D. Dowell, D.A. Williams, L.J. Field (2004) Haematopoietic stem cells do not transdifferentiate into cardiac myocytes in myocardial infarcts. Nature 428 : 664-668.

Noiseux, N., M. Gnecchi, M. Lopez-Ilasaca, L. Zhang, S.D. Solomon, A. Deb, V.J. Dzau, R E. Pratt (2006) Mesenchymal stem cells overexpressing Akt dramatically repair infarcted myocardium and improve cardiac function despite infrequent cellular fusion or differentiation. Mol Ther 14: 840-850.

Nygren, J.M., S. Jovinge, M. Breitbach, P. Sawen, W. Roll, J. Hescheler, J. Taneera, B.K. Fleischmann, S.E. Jacobsen (2004) Bone marrow-derived hematopoietic cells generate cardiomyocytes at a low frequency through cell fusion, but not transdifferentiation. Nat Med 10: 494-501.

Oh, H., S.B. Bradfute, T.D. Gallardo, T. Nakamura, V. Gaussin, Y. Mishina, J. Pocius, L.H Michael, R.R. Behringer, D.J. Garry, M.L. Entman, M.D. Schneider (2003) Cardiac progenitor cells from adult myocardium: homing, differentiation, and fusion after infarction. Proc Natl Acad Sci USA 100: 12313 12318.

Orlic, D., J. Kajstura, S. Chimenti, I. Jakoniuk, S.M. Anderson, B. Li, J. Pickel, R. McKay, B. Nadal-Ginard, D.M. Bodine, A. Leri, P. Anversa (2001b) Bone marrow cells regenerate infarcted myocardium. Nature 410: 701705.

Orlic, D., J. Kajstura, S. Chimenti, F. Limana, I. Jakoniuk, F. Quaini, B. Nadal-Ginard, D.M. Bodine, A. Leri, P. Anversa (2001a) Mobilized bone marrow cells repair the infarcted heart, improving function and survival. Proc Natl Acad Sci USA 98: 10344-10349.

Quaini, F., K. Urbanek, A.P. Beltrami, N. Finato, C.A. Beltrami, B. Nadal-Ginard, J. Kajstura, A. Leri, P. Anversa (2002) Chimerism of the transplanted heart. N Engl J Med 346: 5-15.

Ripa, R.S., E. Jorgensen, Y. Wang, J.J. Thune, J.C. Nilsson, L. Sondergaard, H.E. Johnsen, L. Kober, P. Grande, J. Kastrup (2006) Stem cell mobilization induced by subcutaneous granulocyte-colony stimulating factor to improve cardiac regeneration after acute ST-elevation myocardial infarction: result of the double-blind, randomized, placebo-controlled stem cells in myocardial infarction (STEMMI) trial. Circulation 113: 1983 1992.

Rubart, M., K.B. Pasumarthi, H. Nakajima, M. H. Soonpaa, H.O. Nakajima, L.J. Field (2003) Physiological coupling of donor and host cardiomyocytes after cellular transplantation. Circ Res 92: 1217-1224. 
Rubart, M., M.H. Soonpaa, H. Nakajima, L.J. Field (2004) Spontaneous and evoked intracellular calcium transients in donor-derived myocytes following intracardiac myoblast transplantation. J Clin Invest 114: 775-783.

-Rubart, M., L.J. Field (2006) Cardiac repair by embryonic stem-derived cells. Handb Exp Pharmacol 174: 73-100.

-Schachinger, V., S. Erbs, A. Elsasser, W. Haberbosch, R. Hambrecht, H. Holschermann, J. Yu, R. Corti, D.G. Mathey, C.W. Hamm, T. Suselbeck, B. Assmus, T. Tonn, S. Dimmeler, A.M. Zeiher (2006) Intracoronary bone marrow-derived progenitor cells in acute myocardial infarction. N Engl J Med 355: 1210-1221.

-Schroeder, M., S. Niebruegge, A. Werner, E. Willbold, M. Burg, M. Ruediger, L.J. Field, J. Lehmann, R. Zweigerdt (2005) Differentiation and lineage selection of mouse embryonic stem cells in a stirred bench scale bioreactor with automated process control. Biotechnol Bioeng 92: 920-933.

- Scorsin, M., A. Hagege, J.T. Vilquin, M. Fiszman, F. Marotte, J.L. Samuel, L. Rappaport, K. Schwartz, P. Menasche (2000) Comparison of the effects of fetal cardiomyocyte and skeletal myoblast transplantation on postinfarction left ventricular function. J Thorac Cardiovasc Surg 119: 1169-1175.

-Siminiak, T., R. Kalawski, D. Fiszer, O. Jerzykowska, J. Rzezniczak, N. Rozwadowska, M. Kurpisz (2004) Autologous skeletal myoblast transplantation for the treatment of postinfarction myocardial injury: phase I clinical study with 12 months of follow-up. Am Heart J 148: 531-537.
Siminiak, T., D. Fiszer, O. Jerzykowska, B. Grygielska, N. Rozwadowska, P. Kalmucki, M. Kurpisz (2005) Percutaneous trans-coronary-venous transplantation of autologous skeletal myoblasts in the treatment of postinfarction myocardial contractility impairment: the POZNAN trial. Eur Heart J 26: 1188-1195.

Soonpaa, M.H., G.Y. Koh, M.G. Klug, L.J. Field (1994) Formation of nascent intercalated disks between grafted fetal cardiomyocytes and host myocardium. Science 264: 98-101.

Taylor, D.A., B.Z. Atkins, P. Hungspreugs, T.R. Jones, M.C. Reedy, K.A. Hutcheson, D.D. Glower, W.E. Kraus (1998) Regenerating functional myocardium: improved performance after skeletal myoblast transplantation. Nat Med 4: 929-933.

Valgimigli, M., G.M. Rigolin, C. Cittanti, P. Malagutti, S. Curello, G. Percoco, A.M. Bugli, M. Della Porta, L.Z. Bragotti, L. Ansani, E. Mauro, A. Lanfranchi, M. Giganti, L. Feggi, G. Castoldi, R. Ferrari (2005) Use of granulocyte-colony stimulating factor during acute myocardial infarction to enhance bone marrow stem cell mobilization in humans: clinical and angiographic safety profile. Eur Heart J 26: 1838-1845.

Wang, X., Q. Hu, Y. Nakamura, J. Lee, G. Zhang, A.H. From, J. Zhang (2006) The role of the sca-1+/CD31- cardiac progenitor cell population in postinfarction left ventricular remodeling. Stem Cells 24: 1779-1788.

Wang, Y., K. Tagil, R.S. Ripa, J.C. Nilsson, S. Carstensen, E. Jorgensen, L. Sondergaard, B. Hesse, H.E. Johnsen, J. Kastrup (2005) Effect of mobilization of bone marrow stem cells by granulocyte colony stimulating factor on clinical symptoms, left ventricular perfusion and function in patients with severe chronic ischemic heart disease. Int J Cardiol 100: 477-483.
Wollert, K.C., G.P. Meyer, J. Lotz, S. RingesLichtenberg, P. Lippolt, C. Breidenbach, S. Fichtner, T. Korte, B. Hornig, D. Messinger, L. Arseniev, B. Hertenstein, A. Ganser, H. Drexler (2004) Intracoronary autologous bone-marrow cell transfer after myocardial infarction: the BOOST randomised controlled clinical trial. Lancet 364: 141-148.

Wu, S.M., Y. Fujiwara, S.M. Cibulsky, D.E. Clapham, C.L. Lien, T.M. Schultheiss, S.H. Orkin (2006) Developmental origin of a bipotential myocardial and smooth muscle cell precursor in the mammalian heart. Cell 127: 1137-1150.

Xue, T., H.C. Cho, F.G. Akar, S.Y. Tsang, S.P. Jones, E. Marban, G.F. Tomaselli, R.A. Li (2005) Functional integration of electrically active cardiac derivatives from genetically engineered human embryonic stem cells with quiescent recipient ventricular cardiomyocytes: insights into the development of cell-based pacemakers. Circulation 111: 1120.

Zohlnhofer, D., I. Ott, J. Mehilli, K. Schomig, F. Michalk, T. Ibrahim, G. Meisetschlager, J. von Wedel, H. Bollwein, M. Seyfarth, J. Dirschinger, C. Schmitt, M. Schwaiger, A. Kastrati, A. Schomig (2006) Stem cell mobilization by granulocyte colony-stimulating factor in patients with acute myocardial infarction: a randomized controlled trial JAMA 295: 1003-1010. 